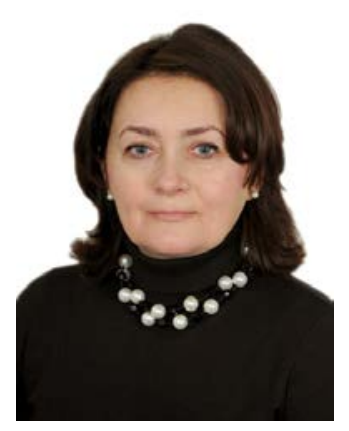

\title{
О. О. Машкаринець
}

Львівський національний медичний університет

імені Данила Галицького

\section{Поширеність і особливості перебігу хронічного катарального гінгівіту у дівчат із порушенням менструального циклу}

Вступ. Здоров'я дітей і підлітків є об'єктивним критерієм соціального благополуччя суспільства. Сучасні дослідження $[6,7,9]$ констатують погіршення показників здоров'я у підлітків. Особливо тривожить багаторазове збільшення кількості функціональних розладів репродуктивної системи у дівчаток $[3,4]$.

Понад 60,0 \% пацієнтів, що звертаються до дитячого гінеколога, страждають від різних порушень менструальної функції, що зумовлено віковою нестабільністю системи її регуляції в період статевого дозрівання і високою чутливістю до різних екзо- та ендогенних чинників. Якщо у дівчаток дошкільного віку переважають запальні захворювання зовнішніх статевих органів, то у дівчат пубертатного періоду - порушення менструального циклу (МЦ) [1].

Порушення становлення оваріоменструальної функції внаслідок недостатньої продукції естрогенів $\epsilon$ чинником ризику виникнення патологічних процесів у тканинах пародонта. Доведено [5, 8], що у дівчат із порушенням становлення менструальної функції патологічні процеси в тканинах пародонта виникають частіше, ніж у їхніх однолітків, що мають регулярний МЦ. Серед захворювань пародонта у дівчат із порушенням МЦ частіше трапляється хронічний катаральний гінгівіт (ХКГ) [5]. Про це свідчать поодинокі дослідження, результати яких не дають змоги обгрунтувати комплекс профілактичних заходів.

Мета дослідження. Дослідити поширеність та особливості перебігу хронічного катарального гінгівіту в дівчат із порушенням менструального циклу та практично здорових.

Матеріали й методи дослідження. Для вивчення поширеності захворювань тканин пародонта обстежено 91 дівчину віком 15-16 років із порушенням МЦ, які перебували на диспансерному обліку в підліткових гінекологічних кабінетах міських комунальних поліклінік № 4, № 5, № 6 м. Львова та на стаціонарному лікуванні в підлітковому гінекологічному відділенні Львівської обласної дитячої спеціалізованої клінічної лікарні. До контрольної групи увійшли 112 практично здорових дівчат цього ж віку загальноосвітніх шкіл № 1, № 7, № 19, № 91, № 21 м. Львова. Стоматологічне обстеження проводили 3 дозволу батьків та керівництва медичних закладів. Діагностику захворювань пародонта здійснювали згідно з систематикою захворювань пародонта М. Ф. Данилевського [2]. Під час огляду порожнини рота відзначали колір, рельєф, стан ясенних сосочків, наявність місцевих подразнювальних чинників (немінералізовані та мінералізовані зубні відкладення). Патологічні зміни в тканинах пародонта, ступінь важкості їх ураження оцінювали за допомогою папілярно-маргінально-альвеолярного індексу (ПМАІ) для визначення ступеня важкості ХКГ в модифікації К. Парма [12], індексу кровоточивості [11], індексу С. П. Рамфйорда, який дає повне уявлення про ступінь запалення ясен та резорбцію кісткової тканини [13], комплексного пародонтального індексу (КомпПІ) для групового визначення пародонтального статусу [2], комунального пародонтального індексу (КПІ) для оцінки поширеності й інтенсивності ураження тканин пародонта [10].

Отриманий цифровий матеріал опрацьовували за допомогою статистичного аналізу з використанням t-критерію Стьюдента.

Результати дослідження та їх обговорення. Завдяки аналізу результатів стоматологічного обстеження виявлено значно більшу поширеність захворювань тканин пародонта у групі дівчат із патологічним перебігом МЦ $(87,85 \pm 3,15 \%)$, ніж у групі практично здорових $(53,63 \pm 3,36 \% ; p<0,001)$. Серед обстежених обох груп (див. рисунок) переважно зафіксовано 
гінгівіт - 79,42 $\pm 3,91 \%$ у групі дівчат із патологічним перебігом МЦ проти 50,89 $\pm 3,37$ \% у групі практично здорових $(p<0,001)$.

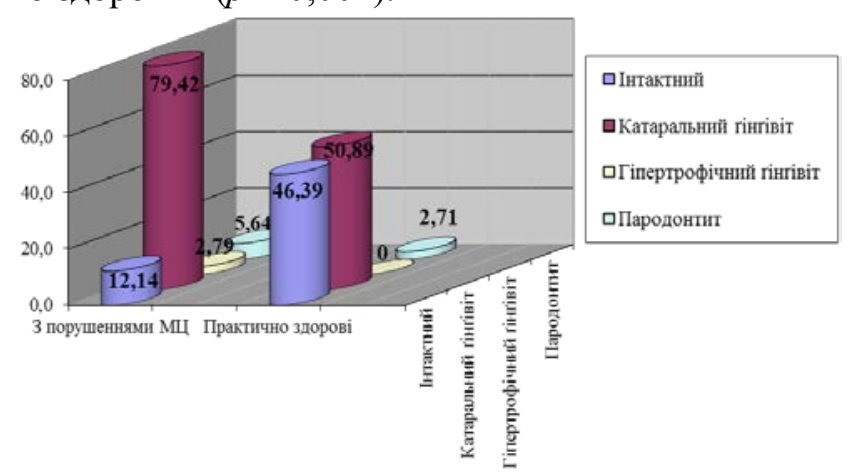

Поширеність захворювань тканин пародонта у дівчат із порушенням менструального циклу та практично здорових.

Дівчат із інтактним пародонтом за наявності розладів МЦ вчетверо менше $(12,14 \pm 3,15 \%$, проти 46,39 $\pm 4,71 \% ; p<0,001)$, ніж тих, у кого порушень МЦ не виявлено.

Гіпертрофічний гінгівіт за наявності порушень МЦ діагностовано у $2,79 \pm 1,59 \%$ дівчат і не зафіксовано у практично здорових. Поширеність пародонтиту у дівчат із порушенням МЦ та практично здорових становить $5,64 \pm 2,52 \%$ і 2,71 $\pm 1,10 \%$ відповідно $(p>0,05)$.

Серед гінгівітів переважав ХКГ - у 88,63 $\pm 3,27 \%$. $\mathrm{У}$ деяких випадках діагностовано загострення хронічного запального процесу ясен $(7,95 \pm 2,71 \%)$.

Важкість клінічного перебігу ХКГ оцінювали за допомогою ПМАІ. Аналіз ступенів важкості ХКГ у дівчат із порушенням МЦ та практично здорових цього ж віку показав, що в обох групах переважав легкий ступінь ХКГ: у 65,38 \pm 5,38 \% дівчат із порушенням МЦ проти 76,90 $\pm 3,98 \%$ у практично здорових $(p>0,05)$. Відсоток дівчат із середнім ступенем важкості ХКГ трохи вищий за наявності порушення МЦ і становив 24,35 $\pm 4,85$ \% порівняно 3 дівчатами 3 нормальним МЦ $(19,29 \pm 3,73 \%)$. Важкий ступінь ХКГ втричі частіше траплявся у дівчат із порушенням МЦ (у 10,25 $\pm 3,43$ \% проти 3,81 $\pm 1,81 \%$ без порушень МЦ; $p>0,05)$.

$\mathrm{У}$ дівчат із патологічним перебігом МЦ зафіксовано переважно генералізований гінгівіт (у 69,23 $\pm 5,22$ $\%$ ), тоді як локалізований - у 30,76 $\pm 5,22 \%$. У практично здорових дівчат генералізований і локалізований гінгівіт реєстрували майже з однаковою частотою - у 52,67 $\pm 4,71 \%$ та 47,32 $\pm 4,71 \%$ відповідно.
Під час проведення клінічних досліджень із використанням пародонтальних індексів виявлено значно вищі показники у дівчат із порушенням МЦ порівняно з практично здоровими.

Середнє значення індексу ПМАІ відповідає легкому ступеню важкості з вищим показником у групі дівчат із порушеним МЦ (у 23,42 $\pm 1,56 \%$ ) проти $17,03 \pm 1,86 \%$ у групі практично здорових дівчат $(p<0,02)$. Індекс С. П. Рамфйорда в обстежених групах дівчат свідчать про ураження ясен легкого ступеня і становить $1,12 \pm 0,09$ бала у дівчат із порушенням МЦ та 1,09 $\pm 0,52$ бала у практично здорових $(p>0,05)$. Вищим був показник кровоточивості ясен у дівчат із розладами МЦ $(0,40 \pm 0,04$ бала проти 0,32 $\pm 0,03$ бала у дівчат без розладів МЦ; $p>0,05)$. Суттєво відмінними є значення індексу КомпПІ, коли показник $1,25 \pm 0,07$ бала у дівчат із порушеним МЦ вказує на ураження тканин пародонта легкого ступеня, порівняно з практично здоровими, де значення $0,91 \pm 0,06$ бала відповідає менше ризику захворювання $(p<0,001)$.

Результати визначення індексу КПІ у дівчат із порушенням МЦ свідчать про нижчу кількість у них здорових секстантів $(3,24 \pm 0,05)$, ніж у практично здорових $(4,53 \pm 0,03 ; p<0,001)$. Кількість уражених секстантів становила відповідно 2,76 $\pm 0,11$ проти $1,47 \pm 0,14(p<0,001)$. Серед них кількість секстантів із кровоточивістю у дівчат із порушенням МЦ становила $1,95 \pm 0,07$ (високий рівень), що майже вдвічі більше, ніж у практично здорових $(1,02 \pm 0,11$ - помірний рівень; $p<0,001)$, а секстантів із зубним каменем $-0,81 \pm 0,04$ проти $0,45 \pm 0,03(p<0,001)$. Наявність зубного каменю у дівчат із порушенням МЦ досягла 38,46 \% (низький рівень) порівняно з практично здоровими (9,34 \% - низький рівень).

Висновки. Поширеність захворювань тканин пародонта серед дівчат із патологічним перебігом менструального циклу (у $87,85 \pm 3,15 \%$ ) достовірно вища порівняно з практично здоровими дівчатами (у 53,63 $\pm 3,36 \%$ ). Серед гінгівітів переважає хронічний катаральний гінгівіт (у 88,63 $\pm 3,27 \%$ ), а пародонтальні індекси мають значно вищі показники у дівчат із порушенням менструального циклу, ніж у практично здорових. Отримані результати можуть бути використані для визначення обсягу та змісту профілактичної допомоги й лікування дівчат із порушенням менструального циклу.

\section{Список літератури}

1. Вовк ИБ. Диагностика и лечение заболеваний пубертатного периода. Медицинские аспекты здоровья женщины. 2009;9:20-23 (Vovk I. Diagnosis and treatment of puberty diseases. Medical Aspects of Women's Health. 2009;9:20-23).

2. Данилевский НФ, Борисенко АВ. Заболевания пародонта. К. : Здоров'я, 2000. 464 c. (Danilevsky N, Borisenko A. Periodontal diseases. Kyiv : Health, 2000. 464 p.).

3. Диннік ВО. Пубертатні маткові кровотечі на тлі пізнього менархе. Вісник наукових досліджень. 2005;4:38-41 (Dinnik V. Puberty uterus bleeding on the background menarche. Research Journal. 2005;4:38-41).

4. Левенець СО, Диннік ВО, Перевозчиков ВВ та ін. Динаміка показників статевого розвитку дівчаток за останні 20 років. Педіатрія, акушерство та гінекологія. 2003;5:41-42 (Levenets S, Dinnik V, Perevozchikov V et al. Dynamics indexes of girls sexual development for past 20 years. Pediatrics, Obstetrics and Gynecology. 2003;5:41-42). 
5. Майборода ТО. Структурно-функціональні порушення тканин пародонту та скелету у дівчаток пубертатного віку за функціональної недостатності гонад та шляхи їх корекції [дисертація]. Київ; 2003. 18 с. (Mayboroda TO. Structural and functional disorders of the periodontal tissues and skeletal girls at puberty age and functional insufficiency of gonads and their correction route [dissertation]. Kiyv; 2003. 18 p.).

6. Неділько ВП, Камінська ТМ, Руденко СА, Пінчук ЛП. Стан здоров’я дітей старшого шкільного віку. Здоровье ребенка. 2011;2:21-23 (Nedilko V, Kaminska T, Rudenko S, Pinchuk L. Health Protection childrens senior schoolchildren. Child Health. 2011:2;21-23).

7. Неділько ВП, Чухраєв МВ. Здоров'я дітей і фактори, які негативно впливають на його показники. В кн.: Актуальні проблеми педіатрії: матеріали VII конгресу педіатрів України: тези доп. К., 2011:103-104 (Nedilko V, Chuhraev M. Children's Health and the factors which affect its performance. In.: Actual problems of pediatrics. Materials VII Congress of Pediatricians of Ukraine: Thesis. Kyiv, 2011:103-104).

8. Поворознюк ВВ, Татарчук ТВ, Майборода ТО та ін. Стан тканин пародонта та скелета у дівчаток пубертатного віку в нормі та при відхиленнях статевого розвитку. Матеріали I (8) з’їзу Асоціації стоматологів України; Київ, 30 листоп-2 груд. К., 1999:82-83 (Povoroznyuk V, Tatarchuk T, Mayboroda T et al. Status of periodontal tissues and skeletal girls puberty age in normal and deviations sexual development. Materials of Congress I (8) of Association dentists Ukraine; Kyiv, 30 Nov- 2 Dec. K., 1999:82-83.

9. Тяжка ОВ, Казакова ЛМ, Строй ОА, Васюкова ММ, Антошкіна АМ, Вакуловська ТО та ін. Сучасні особливості стану здоров’я дітей молодшого та середнього шкільного віку м. Києва. Здоровье ребенка. 2011;4:33-34 (Tyаzhka O, Kazakova L, Stroy O, Vasyukova M, Antoshkina A, Vakulovsky T et al. Modern features of the health status of children of primary and secondary school in Kyiv. Child Health. 2011;4:33-34).

10. Хоменко ЛО. Терапевтическая стоматология детского возраста. К. : Книга плюс, 2010. 524 c. (Khomenko L. Therapeutic dentistry of childhood. Kyiv: Book plus, 2010. 524 p.).

11. Muhlemann HR. Dingival sulcus bleeding - a leading symptom in initial gingivitis. Helv Odontol Acta. 1971;15:107-110.

12. Parma C. Parodontopathien. Leipzig : I.A. Verlag, 1960:203.

13. Ramfjord SP. Indieces for prevalence and indicence of periodontal disease. J Periodontol. 1959;30:51-54. https://doi. org/10.1902/jop.1959.30.1.51

Стаття надійшла до редакції журналу 26 січня 2017 р.

\section{Поширеність і особливості перебігу хронічного катарального гінгівіту у дівчат із порушенням менструального циклу}

\section{О. О. Машкаринець}

Вступ. Порушення становлення оваріоменструальної функції внаслідок недостатньої продукції естрогенів $€$ чинником ризику виникнення патологічних процесів у тканинах пародонта.

Мета. Дослідити поширеність і особливості перебігу хронічного катарального гінгівіту в дівчат із порушенням менструального циклу (МЦ) та практично здорових.

Матеріали й методи. Обстежено 91 дівчину 15-16 років із порушенням МЦ та для порівняння 112 практично здорових дівчат такого ж віку.

Результати. Поширеність захворювань тканин пародонта у групі дівчат із патологічним перебігом МЦ значно вища $(87,85 \pm 3,15 \%)$ порівняно з групою практично здорових $(53,63 \pm 3,36 \%),(p<0,001)$. Серед обстежених дівчат обох груп траплявся переважно катаральний гінгівіт - 79,4 $\pm 3,91$ \% у групі дівчат із патологічним перебігом МЦ проти 50,9 $\pm 3,37 \%$ у групі практично здорових $(p=0,001)$. Переважав хронічний катаральний гінгівіт $(88,63 \pm 3,27 \%$ ). Гіпертрофічний гінгівіт за наявності порушень МЦ діагностовано у $2,79 \pm 1,59$ \% дівчат і не виявлено серед практично здорових. Поширеність пародонтиту серед дівчат із порушенням МЦ і практично здорових становить 5,64 $\pm 2,52 \%$ та 2,71 $\pm 1,10 \%$ відповідно $(p>0,05)$.

Висновки. Поширеність захворювань тканин пародонта у групі дівчат із патологічним перебігом менструального циклу (у 87,85 $\pm 3,15 \%$ ) достовірно вища порівняно з групою практично здорових дівчат (у 53,63 \pm

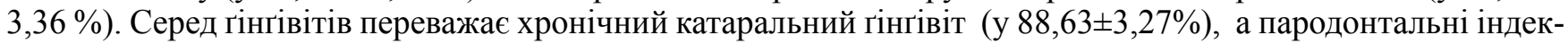
си мають значно вищі показники у дівчат із порушенням менструального циклу порівняно 3 практично здоровими дівчатами.

Отримані результати можуть бути використані для визначення потреб у профілактичній допомозі та лікуванні дівчат із порушеннями менструального циклу.

Ключові слова: хронічний катаральний гінгівіт, дівчата, патологічний перебіг менструального циклу. 


\section{Prevalence and Peculiarities of Clinical Course of Chronic Catarrhal Gingivitis in Girls with Menstrual Cycle Disturbances}

\section{O. Mashkarynets}

Introduction. More than $60.0 \%$ of girls of pubertal period of growth suffered from different disturbances of menstrual functions. It is known that pathological processes in periodontal tissues are diagnosed more often among girls with disturbances of menstrual function comparing to the girls of the same age with regular menstrual cycle.

Aim. To investigate the frequency and clinical appearance of the chronic catarrhal gingivitis in girls with disturbances of menstrual cycle and healthy girls.

Materials and methods. There were examined 91 girls of 15-16 years in order to study the frequency of periodontal tissues diseases. Examined girls were on the dispansary account in teenager gynecology rooms of Lviv Municipal Polyclinic N 4, 5, 6 and on the treatment in the teenager gynecology department of Lviv Regional Pediatric Specialized Clinical Hospital. Control group consisted of 112 healthy girls of the same age from schools N 1, 7, 19, 91, 21 from Lviv. Diagnostics of periodontal tissues diseases was carried out according to M. F. Danylevskiy's classification. The colour, relief, the state of the gindival papillae, presence of local irritating factors was determined during oral cavity examination. Pathological changes in periodontal tissues, the stage of process severity were estimated with the help of the following indicis:papillar-marginal-alveolar index; index of bleeding; index of S. P. Ramfjord; complex periodontal index; community periodontal index.

Results. Pathological processes in periodontal tissues in girls with pathological course of menstrual cycle (MC) have been studied insufficiently. There were examined 91 girls of 15-16 years with MC disturbances and 112 healthy girls of the same age (control group). It was found that the prevalence of inflammatory periodontal diseases in the group of girls with pathological course of $\mathrm{MC}$ is significantly higher $(87.85 \pm 3.15 \%)$, comparing to the control group $(53.63 \pm 3.36 \%),(p<0.001)$. Catarrhal gingivitis was diagnosed mostly among examined girls from both groups. The prevalence of catarrhal gingivitis in the group of girls with pathological course of MC is higher (79.40 $\pm 3.91 \%$ ) comparing to the same index of the girls from the control group $(50.9 \pm 3.37 \%),(p<0.001)$. It was established that the chronic catarrhal gingivitis prevailed $(88.63 \pm 3.27 \%)$ among all gingivitis. Hypertrophic gingivitis in girls with menstrual cycle disturbances was diagnosed in $2.79 \pm 1.59 \%$ persince and was abcesnt in healhy girls. The periodontitis frequency in girls with menstrual cycle disturbances and healhy girls is $5.64 \pm 2.52 \%$ and $2.71 \pm$ $1.10 \%$, accordingfly $(p>0.05)$. Clinical investigations with using of periodontal indices let us to reveal significantly higher indicis in girls with pathological course of MC comparing to the control group.

Conclusions. The prevalence of periodontal tissue diseases in girls with a pathologic course of the menstrual cycle $(87.85 \pm 3.15 \%)$ is significantly higher in comparison with the group of practically healthy girls $(53.63 \pm$ $3.36 \%)$. Among gingivitis, the chronic catarrhal gingivitis predominates $(88.63 \pm 3.27 \%)$. Also periodontal indices are significantly higher in girls with menstrual disorders, compared to practically healthy girls. The results can be used to determine the need of preventive care and treatment for the girls with menstrual disorders.)

Recived data is a base for determination of need of preventive help and treatment in girls with menstrual cycle disturbances.

Keywords: chronic catarrhal gingivitis, girls, pathological course of menstrual cycle. 